\author{
Katarzyna Anna Dadańskaa) \\ (D) https://orcid.org/0000-0003-1674-8665
}

\title{
Ustanawianie ograniczonych praw rzeczowych w prawie prywatnym międzynarodowym - uwagi na tle statutu rzeczowego i jego rozgraniczenia
}

\begin{abstract}
In international trade, it is essential to determine the scope of the law applicable to property rights, i.e. the law applicable to the assessment of rights in rem. Article 41 of the Polish Private International Law Act uses the connecting factor of the situs rei. The competence of legis rei sitae regarding rights in rem should not be challenged when the subject of rights in rem is tangible property. If, however, the subject of rights in rem is not a tangible object but in a claim or other type of a right, then there is an urgent need to seek other ways of establishing the law applicable to the formation of such rights. In addition, there is a recurrent problem with the proper delimitation with the laws applicable to other issues, i.e. the determination of the law applicable to the assessment of the effectiveness of the acquisition of a limited right in rem, and the question of the so-called adaptation and qualification.

The purpose of the present study is to determine the law applicable to the establishment of limited property rights. Using the dogmatic-legal, comparative and complementary historical methods, the provisions of Article 41 of the Private International Law Act are evaluated, and conclusions are drawn de lege ferenda.
\end{abstract}

Keywords: limited property rights, property charter, establishment of limited property rights

a) Dr, Uniwersytet Szczeciński, Instytut Nauk Prawnych. 


\section{Uwagi wprowadzające}

Pojmowanie na świecie praw rzeczowych nie jest jednolite. Odmiennie w poszczególnych państwach kształtuje się treść własności i innych praw rzeczowych, w tym ograniczonych praw rzeczowych i ich katalog. Również określenie przedmiotów ograniczonych praw rzeczowych jest różnie ujmowane. Rozmaite są mechanizmy powstawania, przenoszenia, zmiany treści, określania pierwszeństwa oraz wygasania praw rzeczowych. Z tych powodów w obrocie międzynarodowym istotne znaczenie ma określenie prawa właściwego do oceny praw rzeczowych ${ }^{1}$.

Polska ustawa kolizyjna z 2011 r. $^{2}$ przewiduje w art. 41, że „Własność i inne prawa rzeczowe podlegają prawu państwa, w którym znajduje się ich przedmiot. Nabycie i utrata własności, jak również nabycie i utrata oraz zmiana treści lub pierwszeństwa innych praw rzeczowych, podlegaja prawu państwa, w którym przedmiot tych praw znajdował się w chwili, gdy nastąpiło zdarzenie pociagające za sobą wymienione skutki prawne". Przytoczona regulacja wykorzystuje łącznik miejsca położenia rzeczy - situs rei3. Rozwiązanie to ma długą tradycję, jeśli chodzi o prawa rzeczowe na nieruchomości ${ }^{4}$. W odniesieniu do praw na rzeczach ruchomych konkurencyjna wobec zasady legis rei sitae była zasada mobilia personam sequuntur5, która sporadycznie pojawia się w niektórych współczesnych ustawach kolizyjnych w odniesieniu do rzeczy osobistych podróżnego ${ }^{6}$. Dla praw rzeczowych na statku powietrznym i wodnym

${ }^{1}$ J. Górecki: Kolizyjne prawo rzeczowe, „Studia Prawa Prywatnego” 2014, Z. 3 (34) - 4(35), s. 5; Idem: Prawa rzeczowe i posiadanie $w$ projekcie ustawy o prawie prywatnym międzynarodowym, „Problemy Współczesnego Prawa Międzynarodowego, Europejskiego i Porównawczego" 2009, t. 7, s. 7 i n.; Idem: w: Prawo prywatne międzynarodowe. Komentarz. Red. M. Pazdan. Warszawa 2018, kom. do art. 41, Legalis.

${ }^{2}$ Ustawa z dnia 4 lutego 2011 r. prawo prywatne międzynarodowe (tekst jedn. Dz.U. z 2015 r. poz. 1792 ze zm.), dalej: p.p.m.

${ }^{3}$ Zob. J. Kosik: Prawa rzeczowe ograniczone $w$ kodeksie cywilnym $i w$ artykule 24 prawa prywatnego międzynarodowego, „Studia Prawnicze” 1970, Nr 26-27, s. 58; s. 58; E. Drozd: Nabycie $i$ utrata praw rzeczowych na rzeczy ruchomej $w$ prawie prywatnym międzynarodowym (Wpływ zmiany miejsca położenia rzeczy na właściwość prawa), Kraków 1977, s. 5; K. Kruczalak: Prawa rzeczowe w ustawie o prawie prywatnym międzynarodowym, „Kwartalnik Prawa Prywatnego” 2000, Nr 3, s. 613.

${ }^{4}$ J. Górecki: Kolizyjne..., s. 5; H. Stoll: Internationales Sachenrecht, w: J. von Staudingers Kommentar zum Bürgerlichen Gesetzbuch mit Einführungsgesetz und Nebengesetzen, Berlin 1996, s. 69.

${ }^{5}$ J. Górecki: Kolizyjne..., s. 5; Idem, w: Prawo prywatne międzynarodowe. Komentarz. Red. M. Pazdan, kom. do art. 41.

${ }^{6} \mathrm{~W}$ myśl tej zasady prawa rzeczowe na rzeczach ruchomych podlegają prawu ustalanemu w oparciu o łącznik personalny (np. zwykły pobyt, obywatelstwo) powiązany z oso- 
oraz na pojeździe szynowym art. 42 p.p.m. przewiduje, że podlegają one prawu państwa, w którym statek lub pojazd jest wpisany do rejestru, a w razie braku rejestru lub wpisu do rejestru, prawu państwa macierzystego portu, stacji lub innego podobnego miejsca. Natomiast prawa rzeczowe na rzeczy w transporcie podlegaja prawu państwa, z którego rzecz wysłano. Jeżeli jednak z okoliczności wynika, że prawa te związane są ściślej z prawem innego państwa, stosuje się prawo tego państwa (art. 43 p.p.m.).

Właściwość legis rei sitae $\mathrm{w}$ odniesieniu do praw rzeczowych nie jest aktualnie podważana, gdy przedmiotem praw rzeczowych jest rzecz $^{7}$, choć moga pojawić się problemy w odniesieniu do rzeczy ruchomych, które moga zmieniać swoje położenie. Jeśli jednak przedmiotem praw rzeczowych nie sa rzeczy (np. prawa, przedsiębiorstwo), to pojawia się potrzeba poszukiwania innych powiązań, przy pomocy których ustalić można prawo właściwe dla oceny, a zatem powstania tych praw ${ }^{8}$. Można postawić tezę, że rozwiązanie kolizyjnoprawne, odwołujace się do miejsca położenia przedmiotu praw rzeczowych (z chwili gdy nastapiło zdarzenie pociągajace za sobą wymienione skutki prawne), przyjęte $\mathrm{w}$ art. 41 ust. 2 p.p.m., nie zawsze pozwoli na jednoznaczną odpowiedź, jakie prawo jest właściwe dla oceny danego ograniczonego prawa rzeczowego, w szczególności jego powstania. Wynika to z faktu, że zdarzenie kreujące powstanie danego ograniczonego prawa rzeczowego nie jest jedynym elementem (przesłanka) konieczna dla oceny stanu faktycznego, od którego norma prawna uzależnia nabycie (czy utratę) prawa rzeczowego ${ }^{9}$. W skład stanu faktycznego, od którego norma uzależnia nabycie albo utratę prawa rzeczowego, obok zdarzeń prawnych wchodzą elementy nie będace zdarzeniami, określane jako pewne stany prawne, kwalifikacje normatywne lub stany psychiczne ${ }^{10}$. Pojawia się problem, według jakiego

bą uprawniona do danej rzeczy. Zob. np. art. 67 ust. 2 BułgU, art. 2618 KC rum. Podaję za: J. Górecki, w: Prawo prywatne międzynarodowe. Komentarz. Red. M. Pazdan, kom. do art. 41.

${ }^{7}$ Zob. W. Ludwiczak: Międzynarodowe prawo prywatne, Warszawa 1996, s. 232; zob. K. Kruczalak: Prawa rzeczowe..., s. 613-614; J. Gołaczyński, P. Rodziewicz: Prawo właściwe dla własności i innych praw rzeczowych, „Monitor Prawniczy” 2011, Nr 22, s. 1198; J. Górecki: Kolizyjne..., s. 5; Idem: Prawo rzeczowe i posiadanie..., s. 7; Idem, w: System Prawa Prywatnego, t. 20B. Red. M. Pazdan. Warszawa 2015, s. 944; M. Pazdan: Prawo prywatne międzynarodowe, Warszawa 2017, s. 262; M. Tomaszewski, w: Prawo prywatne międzynarodowe. Komentarz. Red. J. Poczobut. Warszawa 2017, s. 689-691.

8 J. Górecki, w: Prawo prywatne międzynarodowe. Komentarz. Red. M. Pazdan, kom. do art. 41.

${ }^{9}$ Por. E. Drozd: Nabycie i utrata praw rzeczowych, s. 13, 14-15.

${ }^{10}$ Ibidem, s. 13. 
prawa te elementy powinny podlegać ocenie. Czy ta ocena powinna być dokonana wyłącznie w oparciu o statut rzeczowy czy też w oparciu o inne statuty. I choć w ostatnich latach widoczna jest tendencja do regulowania właściwości prawa dla praw rzeczowych w sposób bardziej szczegółowy niż jeszcze kilkadziesiąt lat temu ${ }^{11}$, pomimo to pojawia się niejednokrotne problem z właściwym rozgraniczeniem statutów rzeczowego, obligacyjnego, stosunków majątkowych małżeńskich, spadkowego czy upadłościowego, czyli określenia prawa właściwego m.in. dla oceny skuteczności ustanowienia ograniczonego prawa rzeczowego oraz zagadnienie tzw. dostosowania i kwalifikacji.

\section{Zdarzenia kreujące ograniczone prawa rzeczowe - prawo polskie}

W prawie polskim do powstania ograniczonego prawa rzeczowego dochodzi zazwyczaj na podstawie umowy, ale także z mocy czynności prawnej jednostronnej ${ }^{12}$, konstytutywnego orzeczenia sądu ${ }^{13}$, decyzji administracyjnej ${ }^{14}$ a nawet $\mathrm{z}$ mocy prawa (ex lege $)^{15}$. Ponadto powstanie, a zatem dojście do skutku rzeczowego, nie zawsze jest tożsame ze zdarzeniem będącym jego źródłem (np. umową o ustanowienie prawa), przykładowo do ustanowienia praw zastawniczych wymagany jest dodatkowo akt jawności - w postaci np. wydania rzeczy, wpisu do rejestru (przy zastawie), czy wpisu do księgi wieczystej (przy hipotece). Zwolennicy tego typu rozumienia pojęcia „ustanowienia” ograniczonego prawa rzeczowego podkreślają jednocześnie, że nie można mówić o ustanowieniu ograniczonego prawa rzeczowego w odniesieniu do tych zdarzeń, które kreuja powstanie ograniczonego prawa rzeczowego ex lege $e^{16}$. Na gruncie polskiego Kodeksu cywilnego ustawodawca posłużył się techniką odesłania do

${ }^{11}$ J. Górecki, w: System..., Tom 20B. Red. M. Pazdan, s. 940-941.

${ }^{12}$ Zob. art. $981^{1} \S 2$ pkt 4 k.c. oraz art. 31 ust. 1 ustawy z dnia 15 stycznia 2015 r. o obligacjach (tekst jedn. Dz.U. z 2018 r. poz. 483 ze zm.

${ }^{13}$ Zob. np. art. 145 , art. 151 , art. 212 , art. $305^{2}$ k.c.

${ }^{14}$ Zob. np. art. 41 i art. 44 ustawy z dnia 29 sierpnia 1987 r. Ordynacja podatkowa, tekst jedn. Dz.U. z 2019 r. poz. 900 ze zm.

${ }^{15}$ Zob. art. art. 432 , art. $588 \S 2$, art. 670 , art. 671 , art. 686 , art. $790,702 \mathrm{w} \mathrm{zw.}$ z art. 694 , art. 773 , art. 790 , art. 802 , art. 850 k.c.

${ }^{16} \mathrm{~K}$. Zaradkiewicz: Konstrukcja umowy o ustanowienie $i$ przeniesienie ograniczonego prawa rzeczowego - węzłowe problemy $i$ uwagi de lege ferenda. W: Zaciaganie i wykonywanie zobowiazań, Materiały III Ogólnopolskiego Zjazdu Cywilistów (Wroc- 
przepisów o przeniesieniu własności, przewidując, że „Z zastrzeżeniem wyjątków w ustawie przewidzianych, do ustanowienia ograniczonego prawa rzeczowego stosuje się odpowiednio przepisy o przeniesieniu własności” (art. $245 \S 1$ k.c.). Z reguły pojęcie „ustanowienie” ograniczonego prawa rzeczowego rozumiane jest w sensie techniczno-prawnym jako rodzaj zdarzenia prawnego: czynność prawna - umowa ${ }^{17}$. Niektórzy jednak autorzy wskazuja, że ustanowienie ograniczonych praw rzeczowych jest możliwe nie tylko na podstawie umowy, ale także innych źródeł ${ }^{18}$. Inni znów podkreślają, że powstanie ograniczonego prawa rzeczowego nie może być utożsamiane $\mathrm{z}$ jego ustanowieniem ${ }^{19}$.

Przedmiotem ograniczonych praw rzeczowych $\mathrm{w}$ prawie polskim sa przede wszystkim rzeczy (nieruchomości i rzeczy ruchome), ale także prawa (wierzytelności, prawa udziałowe, prawa inkorporowane w papierach wartościowych), zespół środków produkcji, zbiór rzeczy (chociażby jego skład był zmienny), zespoły rzeczy i praw (w szczególności przedsiębiorstwo $)^{20}$. Polski ustawodawca wprowadził wyraźnie zamkniętą listę ograniczonych praw rzeczowych (numerus clausus) zaliczając do ograniczonych praw rzeczowych: użytkowanie, służebności, zastaw, spółdzielcze własnościowe prawo do lokalu oraz hipotekę (art. $244 \S 1$ k.c.).

W polskiej doktrynie funkcjonuje kilka koncepcji dotyczących istoty i charakteru umów o ustanowienie ograniczonych praw rzeczowych ${ }^{21}$. Najpopularniejsza, odwołująca się do konstrukcji przeniesienia własności przyjmowanej przez większość doktryny na gruncie art. 155- 156 k.c., to teoria umowy o podwójnym skutku ${ }^{22}$. Zakłada, że zawarcie umowy zobowiąującej do ustanowienia ograniczonego prawa rzeczowego powodu-

ław, 25-27.9.2008 r.). Red. E. Gniewek, K. Górska, P. Machnikowski. Warszawa 2010, s. 505.

${ }^{17}$ E. Gniewek, w: System Prawa Prywatnego, t. 4, Red. E. Gniewek, Warszawa 2007, s. 348 .

18 J. Szachułowicz, w: Komentarz KC, t. I, Warszawa 2005, s. 698.

${ }^{19}$ K. Zaradkiewicz: Konstrukcja umowy, s. 505.

${ }^{20}$ K.A. Dadańska: Prawo rzeczowe, Warszawa 2018.

${ }^{21}$ Zob. szerzej K. Zaradkiewicz: Konstrukcja umowy..., s. 505 n.

${ }^{22}$ Zob. E. Drozd: Przeniesienie własności nieruchomości, Warszawa-Kraków 1974, s. 27 i n.; W.J. Katner: Przeniesienie własności rzeczy ruchomych, „Acta Universitatis Lodzensis. Folia Iuridica” 1988, s. 146; J. Górecki: Przeniesienie własności rzeczy ruchomej, Wrocław 1950, s. 33; J. St. Piątowski, który wskazywał, że „zagadnienie, czy umowa zobowiąująca do przeniesienia własności wywołuje skutki tylko w sferze obligacyjnej, czy też zarazem własność przenosi, była główną osią sporu, który się toczył pod rządem pr.rzecz. Od samego początku prac kodyfikacyjnych ustawodawca starał się spór ten rozstrzygnać na rzecz koncepcji podwójnego skutku i swej niewątpliwej woli w tym zakresie dał wyraz w omawianym przepisie [art. $155 \mathrm{KC}$ - przyp. K.A.D.]", J.St. Piątowski, w: System Prawa Cywilnego, t. II, Prawo własności i inne prawa rzeczowe. Red. J. Ignatowicz. Wrocław-Warszawa-Kraków—Gdańsk 1977, s. 227—228. 
je w istocie ustanowienie tego prawa i jego nabycie przez kontrahenta ${ }^{23}$. Zgodnie z ta teorią umowa ustanowienia ograniczonego prawa rzeczowego rodzi skutki (łącznie ze skutkami rozporządzającymi) z momentem jej zawarcia (w odniesieniu do rzeczy co do tożsamości oznaczonych) ${ }^{24}$. Oczywiście dopuszczalne jest rozdzielnie skutku obligacyjnego i skutku rzeczowego, o ile strony tak postanowiona, albo gdy wymagać tego będzie przepis prawa ${ }^{25}$. Stanowisko takie prezentowane jest także przez judykaturę ${ }^{26}$. Ponadto doktryna odwołuje się do odpowiedniego stosowania do umów ustanawiajacych ograniczone prawo rzeczowe zasady konsensualności (z dość daleko idącymi modyfikacjami w tym zakresie - zob. art. 307 k.c., art. 2 ust. 1 u.z.r. ${ }^{27}$, art. 67 ust. 1 u.k.w.i h. ${ }^{28}$ ) oraz zasady kauzalności ${ }^{29}$.

\section{Kwalifikacja pojęć użytych w art. 41 p.p.m.}

Unifikacja norm kolizyjnych $\mathrm{w}$ ramach UE nie objęła dotychczas norm kolizyjnych wskazujacych prawo właściwe dla własności i innych praw rzeczowych ${ }^{30}$. Różnorodność unormowań praw merytorycznych ${ }^{31}$ skłania do wniosku, iż dokonanie właściwej interpretacji art. 41 p.p.m., która pozwoli na określenie zakresu normy kolizyjnej a następnie wskazanie łącznika określającego prawo właściwe dla ograniczonego prawa rzeczowego podlegającego ocenie, nie będzie możliwe bez określenia takich pojęć jak rzecz (ruchoma, nieruchomość), prawo rzeczowe (ograni-

${ }^{23}$ E. Gniewek, w: System..., t. 4, s. 349.

${ }^{24}$ Ibidem, s. 350.

${ }^{25}$ Por. ibidem, s. $349-350$.

${ }^{26}$ Zob. wyrok z 12.05.2000 r., V CKN 30/00.

${ }^{27}$ Ustawa z dnia 6 grudnia 1996 r. o zastawie rejestrowym i rejestrze zastawów, tekst jedn. Dz. U z 2018 r. poz. 2017 ze zm.

${ }^{28}$ Ustawa z dnia 6 lipca 1982 o księgach wieczystych i hipotece, tekst jedn. Dz.U. z 2018 r. poz. 1916 ze zm., dalej: u.k.w.h.

${ }^{29}$ Zob. E. Gniewek, w: System..., t. 4, s. 349; K. Zaradkiewicz: Konstrukcja umowy..., s. 512 i n.

30 J. Gołaczyński, P. Rodziewicz: Prawo właściwe..., s. 1198. Szerzej na temat procesu unifikacji w obszarze prawa rzeczowego zob. J. Górecki, w: System..., Tom $20 B$, s. 947 i n. Zob. też Ł. Żarnowiec: Wpływ statutu rzeczowego na rozstrzyganie spraw spadkowych — na styku statutów, Warszawa 2018.

${ }^{31} \mathrm{Z}$ uwagi na zakreślone ramy publikacji pomijam kwestię omówienia regulacji ograniczonych praw rzeczowych w poszczególnych krajach Unii Europejskiej. Zob. literaturę przywołaną w przypisie 36 . 
czone prawo rzeczowe), przedmiot praw rzeczowych. W polskiej ustawie kolizyjnej nie wprowadzono normy rozstrzygajacej w oparciu o jakie prawo należy dokonywać kwalifikacji ww. pojęć, choć obce ustawy kolizyjne zawieraja tego typu rozwiazania ${ }^{32}$.

Kwalifikacja pojęć: rzecz (ruchoma, nieruchomość), prawo rzeczowe, ograniczone prawo rzeczowe, przedmiot praw rzeczowych - powinna poprzedzać wskazanie prawa właściwego ${ }^{33}$. Oznacza to konieczność ustalenia znaczenia pojęciowego wyrażeń określających zakres norm kolizyjnych w przepisach, w których mowa o własności, innych prawach rzeczowych i o posiadaniu ${ }^{34}$. Niektóre prawa sa bowiem traktowane w jednych państwach jako rzeczowe, a w innych sa one prawami obligacyjnymi. Występują też prawa, którym jedynie sporadycznie nadaje się status praw rzeczowych ${ }^{35}$. Szczegółowe katalogi praw rzeczowych w poszczególnych państwach wykazuja bowiem dość istotne różnice ${ }^{36}$. Wykładnia wyrażeń określających zakres normy kolizyjnej, podejmowana w celu ustalenia przesłanek jej stosowania, określana jest mianem kwalifikacji ${ }^{37}$. Kwalifikacja ma umożliwić stwierdzenie, czy dany stan faktyczny może być przyporządkowany do zakresu określonej normy kolizyjnej. Na równi z tym traktuje się zabiegi zmierzające do wyjaśnienia pojęć użytych na określenie łącznika normy kolizyjnej, o ile w roli łączni-

32 J. Gołaczyński, P. Rodziewicz: Prawo właściwe..., s. 1198. Jako przykład wskazuje się art. 64 (2) bułgarskiego prawa prywatnego międzynarodowego. Przepis art. 64 przewiduje, że posiadanie, prawo własności oraz inne prawa rzeczowe na rzeczach ruchomych i nieruchomościach podlegaja prawu państwa, w którym rzeczy się znajdują (1). Uznanie danej rzeczy za rzecz ruchomą albo nieruchomość, jak również rodzaj prawa rzeczowego ocenia się według prawa, o którym mowa w ust. 1 (2). Zob. P. Ptak: Butgarskie prawo prywatne międzynarodowe, „Kwartalnik Prawa Prywatnego” 2009, z. 1, s. 264. Zob też Ł. Żarnowiec: Wptyw statutu...

${ }^{33}$ J. Górecki: Kolizyjne..., s. 13.

${ }^{34}$ J. Górecki: Kolizyjne..., s. 13 i n.; Idem, w: System..., Tom 20B. Red. M. Pazdan, s. 954 i n.; M. Pazdan: Prawo prywatne międzynarodowe, s. 266; w starszej literaturze zob. E. Drozd: Nabycie i utrata praw rzeczowych, s. 8-10.

${ }^{35}$ J. Górecki, w: System..., Tom 20B. Red. M. Pazdan, s. 954.

${ }^{36}$ Zob. J. Pisuliński,: Ograniczone prawa rzeczowe $w$ wybranych systemach prawnych a przyszła regulacja tych praw w nowym Kodeksie cywilnym, SPP, Z. 4 (11) 2008; R. Cierpiał: Ograniczone prawa rzeczowe $w$ prawie austriackim, „Studia Prawa Prywatnego" 2018, Zeszyt 4 (11), s. 1 i n.; A. Józefiak: Ograniczone praw rzeczowe w prawie francuskim, „Studia Prawa Prywatnego” 2018, Z. 4 (11), s. 17 i n.; Ł. Przyborow ski: Ograniczone praw rzeczowe w prawie niemieckim, „Studia Prawa Prywatnego” 2018, Z. 4 (11), s. 37 i n.; B. Swaczyna: Ograniczone prawa rzeczowe w prawie szwajcarskim, „Studia Prawa Prywatnego” 2018, Z. 4 (11), s. 63 i n.; E. Rablin: Ograniczone praw rzeczowe w prawie włoskim, „Studia Prawa Prywatnego” 2018, Z. 4 (11), s. 89 i n.

${ }^{37}$ M. Pazdan: Prawo prywatne międzynarodowe, s. 60. 
ka występuje węzeł odznaczający się przynajmniej minimalnym „prawnym" zabarwieniem ${ }^{38}$.

Najprostszym rozwiązaniem jest kwalifikacja według merytorycznej lub kolizyjnej legis fori. Wskazuje się także, że najbardziej poprawne byłoby poszukiwanie uniwersalnego pojęcia praw rzeczowych (kwalifikacja autonomiczna). Ponadto w grę wchodzić może jeszcze kwalifikacja według prawa miejsca położenia przedmiotu prawa rzeczowego (poszukiwanie prawa merytorycznego wykorzystywanego do celów kwalifikacyjnych za pomoca łacznika situs rei) oraz na podstawie legem causae (prawo właściwe w danej kwestii) ${ }^{39}$.

Polska ustawa kolizyjna z 2011 r. nie zawiera żadnej wskazówki dotyczącej metody kwalifikacji. Brak także dowodów na kształtowanie się jakiegoś jednolitego stanowiska judykatury ${ }^{40}$. Także stanowisko doktryny nie jest jednolite ${ }^{41}$.

Kwalifikacja według merytorycznej legis fori zakłada, że sąd powinien kierować się wskazówkami zaczerpniętymi z własnego prawa merytorycznego, czyli tak pojmować wyrażenia zawarte w zakresie normy kolizyjnej, jak sa one rozumiane we własnym prawie merytorycznym ${ }^{42}$. Kwalifikacji dokonuje się więc zgodnie z prawem obowiązującym w siedzibie sadu ${ }^{43}$. Z kolei kwalifikacja według prawa merytorycznego właściwego (czyli według legis causae) zakłada, że podlegające kwalifikacji wyrażenia należy pojmować $\mathrm{w}$ taki sposób, w jaki są one rozumiane $\mathrm{w}$ prawie merytorycznym rządzącym danym stosunkiem ${ }^{44}$. Kolejna metoda kwalifikacji zwaną autonomiczną (prawnoporównawczą), której twórcą być był E. Rabel, opiera się na założeniu, że normy prawa prywatnego międzynarodowego, posługując się jakimś określeniem, używają go w znaczeniu specjalnym, własnym, które niekoniecznie pokrywa się ze znaczeniem, w jakim występuje ono w prawie merytorycznym własnym lub określonym obcym. Zatem nie merytorycznoprawna lex fori, lecz

${ }^{38}$ Ibidem.

39 J. Górecki, w: System, Tom 20B. Red. M. Pazdan, 2015, s. 953-954; Idem: Kolizyjne..., s. 13; zob. szerzej M. Pazdan: Prawo prywatne międzynarodowe, s. 7779, 266.

${ }^{40}$ M. Pazdan: Prawo prywatne międzynarodowe, s. 79.

${ }^{41}$ Zob. E. Drozd: Kompetencja statutów, s. 127 i n.; J. Gołaczyński: Prawo prywatne międzynarodowe, Warszawa 2008, s. 254- 255; M. Pazdan: Prawo prywatne międzynarodowe, s. 76-77, 266, M. Pazdan, E. Rott-Pietrzyk, M. Świerczyński, w: System Prawa Prywatnego, Tom 20A. Red. M. Pazdan. Warszawa 2014, s. 303.

${ }^{42}$ Zwolennikami tej metody byli F. Kahn i E. Bartin. Zob. M. Pazdan: Prawo prywatne międzynarodowe, s. 77.

${ }^{43}$ M. Pazdan, E. Rott-Pietrzyk, M. Świerczyński, w: System, Tom 20A. Red. M. Pazdan, s. 311.

${ }^{44}$ Ibidem, s. 312; zob. też E. Drozd: Nabycie i utrata prawa rzeczowych, s. 18. 
sama norma kolizyjna powinna określać przesłanki swego zastosowania. To z kolei prowadzi do postulatu tworzenia i używania przez prawo prywatne międzynarodowe pojęć własnych, autonomicznych w stosunku do pojęć prawa merytorycznego ${ }^{45}$. Wreszcie przeważajaca $\mathrm{w}$ doktrynie teoria kwalifikacji według kolizyjnej legis fori, nazywana też kwalifikacja funkcjonalną zakłada, że wykładnia wyrażeń występujących w normach prawa prywatnego międzynarodowego powinna być dokonywana samodzielnie, na użytek tych norm, niezależnie od tego jak sa one rozumiane we własnym prawie merytorycznym ${ }^{46}$. Pojęcia występujące w normach kolizyjnych prawa prywatnego międzynarodowego pojmować należy w sposób odpowiadający celom, jakie normy te maja do spełnienia, uwzględniając międzynarodową funkcję rozgraniczająca tych norm ${ }^{47}$.

Wydaje się, że przy wykładni pojęć ${ }^{48}$ mających wpływ na określenie zakresu normy zrekonstruowanej z art. 41 p.p.m. najbardziej właściwa jest kwalifikacja na podstawie prawa merytorycznego obowiązujacego $\mathrm{w}$ miejscu położenia przedmiotu tych praw $^{49}$. Jest to kwalifikacja dokonana w oderwaniu od właściwości prawa dla praw rzeczowych ${ }^{50}$. Takie rozwiązanie uwzględnia funkcję łącznika miejsca położenia rzeczy i powiązane jest z koniecznością respektowania prawa obowiązującego w tym miejscu ${ }^{51}$. Metoda ta polega na tzw. odesłaniu w zakresie kwalifikacji (w terminologii niemieckiej: Qualifikationsverweisung). Odesłanie to uwzględnia fakt, że „lex rei sitae wykonuje "kontrolę" na rzecza” co sprzyja międzynarodowej zgodności orzeczeń sądowych ${ }^{52}$. Dla określenia

${ }^{45}$ M. Pazdan, E. Rott-Pietrzyk, M. Świerczyński, w: System, Tom 20A. Red. M. Pazdan, s. 314; M. Pazdan: Prawo prywatne międzynarodowe, s. 78.

${ }^{46}$ Ibidem.

${ }^{47}$ M. Pazdan, E. Rott-Pietrzyk, M. Świerczyński, w: System, Tom 20A. Red. M. Pazdan, s. $314-315$.

${ }^{48}$ Takich jak: rzecz (ruchoma, nieruchomość), prawo rzeczowe (ograniczone prawo rzeczowe), przedmiot praw rzeczowych.

${ }^{49}$ J. Górecki, w: System, Tom 20B. Red. M. Pazdan, s. 954-955; Idem: Kolizyjne..., s. 13 .

${ }^{50}$ E. Drozd: Nabycie i utrata praw rzeczowych, s. 8-9, s. 18.

51 J. Górecki, w: System, Tom 20B. Red. M. Pazdan, s. 955.

${ }^{52}$ E. Drozd: Kompetencja statutów rzeczowego i obligacyjnego $w$ zakresie praw podmiotowych, „Studia Cywilistyczne”, Tom XXX, 1979, s. 134. Za kwalifikacją praw rzeczowych według systemu merytorycznego rei sitae opowiadali się H. Trammer: Sprawy czysto majatkowe $w$ polskim prawie prywatnym międzynarodowym, „Problemy Prawne Handlu Zagranicznego" 1968, Nr 19-20, s. 15; J. Ko sik: Prawa rzeczowe ograniczone $w$ kodeksie cywilnym $i$ art. 24 prawa prywatnego międzynarodowego, „Studia Prawnicze" 1970, Nr 26-27, s. 67; M. Sośniak: Prawo prywatne międzynarodowe, Warszawa 1991, s. 111. W ujęciu F. Zolla: Prawo prywatne międzynarodowe, Kraków 1947, s. 52, za „prawa rzeczowe” w rozumieniu prawa prywatnego międzynarodowego „uważać należy prawa, których przedmiotem (a) są rzeczy lub inne dobra przedstawiające wartość 
pojęcia „rzecz” - będzie to prawo państwa miejsca położenia dobra ${ }^{53}$. Przy czym położenie należy rozumieć $\mathrm{w}$ znaczeniu czysto fizycznym ${ }^{54}$. Według legi rei sitae należy też $\mathrm{w}$ zasadzie ustalić czy $\mathrm{w}$ grę wchodzi nieruchomość czy rzecz ruchoma ${ }^{55}$. Także według miejsca położenia rzeczy należy ustalić, czy dane uprawnienie (zespół uprawnień) ma charakter prawa rzeczowego ${ }^{56}$. Prawo miejsca położenia rzeczy określa zwykle zamknięty katalog praw rzeczowych występujących na terytorium jego obowiązywania i dopiero na jego podstawie można ustalić, czy rozpatrywane prawo mieści się w tym katalogu i czy w tym właśnie zakresie można doń stosować normy kolizyjne dotyczace praw rzeczowych. Jeśli okaże się, że to prawo nie traktuje określonego uprawnienia jako prawa rzeczowego, nie ma podstaw do stosowania art. 41 p.p.m. Miejsce położenia rzeczy powinno mieć zastosowanie przy rozstrzyganiu zagadnienia kwalifikacji, szczególnie wówczas, gdy obce normy kolizyjne nakazują stosować prawo obowiązujące $\mathrm{w}$ tym właśnie miejscu przy kwalifikowaniu rzeczy, np. odróżnianiu ruchomości od nieruchomości ${ }^{57}$. Co istotne, położenie rzeczy wywiera wpływ na właściwość sądu, a w konsekwencji na zastosowanie prawa siedziby sąu w przypadkach, w których prawo to jest właściwe ${ }^{58}$.

Także według prawa merytorycznego legi rei sitae należy rozstrzygnać, czy dane dobro (materialne, niematerialne) może być przedmiotem praw rzeczowych (ograniczonych praw rzeczowych) ${ }^{59}$. Zarówno w przepisach polskiego porząlku prawnego, jak i w systemach prawnych państw obcych dopuszcza się, że poza rzeczami (ruchomymi, nieruchomościami) przedmiotem ograniczonych praw rzeczowych mogą być także prawa ma-

majątkową, a których treścia (b) jest władza bezpośrednia osoby uprawnionej nad tym przedmiotem - władza, która w następstwie swej bezpośredniości jest też bezwzględna, tzn. skuteczna przeciw każdemu trzeciemu". Istnieją też wypowiedzi, które zwracają uwagę na konieczność uwzględniania przy rozstrzyganiu kwestii wątpliwych funkcji norm kolizyjnych, o które tutaj chodzi, i występującego w nich łącznika rei sitae. Tak E. Drozd: Kompetencje statutów, s. 139 i 140; M. Pazdan: Prawo prywatne międzynarodowe, s. 266; M. Pazdan, E. Rott-Pietrzyk, M. Świerczyński, w: System, Tom 20A. Red. M. Pazdan, s. 306, przyp. 710. Także współcześnie dominuje ujęcie kwalifikacji według łącznika situs rei. Zob. M. Pazdan: Prawo prywatne międzynarodowe, s. 266; E. Drozd: Kompetencja statutów s. 130-140; J. Górecki, w: System, T. $20 B$. Red. M. Pazdan, s. 955.

${ }^{53}$ E. Drozd: Nabycie i utrata praw rzeczowych, s. 8.

${ }^{54}$ Ibidem.

${ }^{55}$ Ibidem, s. 9.

${ }^{56}$ Ibidem.

${ }^{57}$ J. Kosik: Zagadnienia prawa rzeczowego $w$ Prawie prywatnym międzynarodowym z 1965 r., „Acta Univesitatis Wratislaviensis. Prawo” 1976, Nr 57, s. 34.

${ }^{58}$ Ibidem.

${ }^{59}$ Ibidem, s. 3. 
jątkowe (zbywalne), prawa inkorporowane w papierach wartościowych, zespoły rzeczy i praw, a nawet zbiory rzeczy ${ }^{60}$.

Przyjąć zatem należy, iż na gruncie art. 41 p.p.m. kwalifikacji pojęć należy dokonywać na podstawie prawa obowiązującego w miejscu położenia przedmiotu tych praw ${ }^{61}$. Jeśli okaże się, że prawo, o które chodzi, nie jest prawem rzeczowym według prawa obowiązującego w miejscu położenia przedmiotu tego prawa, to należy zakwalifikować je jako prawo o innym charakterze (przede wszystkim obligacyjnym) i poddać je prawu ustalonemu $\mathrm{w}$ oparciu o odpowiednie dla niego normy kolizyjne ${ }^{62}$. Natomiast dla kwalifikacji pojęć użytych w art. 42 i 43 p.p.m. ${ }^{63}$, a tym samym dla określenia zakresu normy kolizyjnej w omawianych przypadkach, należy zastosować kwalifikację funkcjonalna ${ }^{64}$. Zastosowanie w tych sytuacjach metody kwalifikacji legi rei sitae nie daje oczekiwanych efektów i nie wykazuje wskazanych powyżej zalet ${ }^{65}$. Kwalifikowanie praw rzeczowych na rzeczach $\mathrm{w}$ transporcie oraz na środkach transportu na podstawie prawa obowiąującego w miejscu aktualnego położenia przedmiotu tego prawa doprowadzić by mogło do objęcia tym pojęciem praw, które według statutu rzeczowego nie sa prawami rzeczowymi ${ }^{66}$. W tym wypadku wyrażenia występujące w art. 42 i art. 43 p.p.m. należy pojmować $\mathrm{w}$ sposób odpowiadajacy celom, jakie te normy maja do spełnienia, uwzględniając rolę łącznika występującego w danej rekonstruowanej normie kolizyjnej. Dokonując wykładni należy zbadać, jakie „interesy” w sferze kolizyjnoprawnej norma ta ma chronić w duchu idei „sprawiedliwości międzynarodowej”"67.

${ }^{60}$ Zob. częściowo odmiennie M. Tomaszewski, w: Prawo prywatne międzynarodowe. Red. J. Poczobut, s. 687-688.

${ }^{61}$ Ibidem, s. 14. Zob. też M. Tomaszewski, w: Prawo prywatne międzynarodowe. Red. J. Poczobut, s. 689.

${ }^{62}$ J. Górecki, w: System, Tom 20B, Red. M. Pazdan, s. 955.

${ }^{63}$ Zgodnie z art. 42 p.p.m. prawa rzeczowe na statku powietrznym i wodnym oraz na pojeździe szynowym podlegaja prawu państwa, w którym statek lub pojazd jest wpisany do rejestru, a w razie braku rejestru lub wpisu do rejestru — prawu państwa macierzystego portu, stacji lub innego podobnego miejsca. W myśl art. 43 p.p.m. prawa rzeczowe na rzeczy w transporcie podlegaja prawu państwa, z którego rzecz wysłano. Jeżeli z okoliczności wynika, iż prawa te są związane ściślej z prawem innego państwa, stosuje się prawo tego państwa.

${ }^{64}$ J. Górecki: Kolizyjne..., s. 14; Idem: w: System, Tom 20B. Red. M. Pazdan, s. 955 - zob. przypis $151 \mathrm{w}$ tej pozycji. Co do kwalifikacji pojęć określających zakres normy kolizyjnej zob. też M. Tomaszewski, w: Prawo prywatne międzynarodowe. Red. J. Poczobut, s. 702-704, 706.

${ }^{65}$ Ibidem, s. 956.

${ }^{66}$ Ibidem, s. 955-956.

${ }^{67}$ M. Pazdan: Prawo prywatne międzynarodowe, s. 78-79. 


\section{4. Łącznik miejsca położenia przedmiotu prawa rzeczowego}

Redakcja art. 41 p.p.m. sugeruje, że z punktu widzenia oceny, czy doszło do powstania (ustanowienia) ograniczonego prawa rzeczowego, fundamentalne znaczenie ma określenie łacznnika miejsca położenia przedmiotu praw rzeczowych ${ }^{68}$. Istotne jest także zamieszczenie w dyspozycji normy kolizyjnej subokreślnika temporalnego (w chwili, gdy nastąpiło zdarzenie pociągające za sobą wymienione skutki prawne). Przez odpowiedni dobór subokreślnika temporalnego, dla łącznika rei sitae, ustawodawca kolizyjny stara się uniknać ewentualnych problemów z ocena, jaka chwila miałaby być najbardziej miarodajna dla ustalenia, czy doszło do powstania danego ograniczonego prawa rzeczowego. Wątpliwości pojawią się wówczas, gdy pod rządami wskazanego za pomoca łącznika normy kolizyjnej statutu rzeczowego dojdzie do realizacji tylko niektórych przesłanek wymaganych do powstania prawa rzeczowego (np. zawarto umowę, a nie doszło do wydania rzeczy albo nie dokonano wpisu do odpowiedniego rejestru) ${ }^{69}$. Sa to tzw. otwarte (niezamknięte) stany faktyczne ${ }^{70}$. W takich przypadkach proponuje się, aby na za pomoca na nowo ustalonego łącznika wskazać statut rzeczowy i na jego podstawie ustalić przesłanki nabycia (powstania) prawa rzeczowego i przesądzić, czy okoliczności, które zaszły przed zmianą statutu moga być brane pod uwage jako uzasadniające nabycie (powstanie) prawa rzeczowego wraz z okolicznościami, które zajdą dopiero po zmianie statutu. Jest to zagadnienie, które rozstrzygać należy na płaszczyźnie prawa materialnego (aktualnego statutu rzeczowego), a nie na płaszczyźnie kolizyjnoprawnej ${ }^{71}$.

O ile łącznik legis rei sitae nie nastręcza większych wątpliwości $\mathrm{w}$ przypadku ustanawiania ograniczonych praw rzeczowych na nieruchomości, a także powstawania tych praw w drodze innych zdarzeń prawnych niż czynność prawna, to już przy rzeczach ruchomych, z uwagi na możliwość ich przemieszczania, może sprawić problemy. Cechą rzeczy ruchomych jest bowiem możliwość przemieszczania ich bez naruszenia

${ }^{68}$ J. Górecki: Kolizyjne..., s. 15; Idem, w: System, Tom 20B. Red. M. Pazdan, s. 957.

69 J. Górecki, w: System, Tom 20B, Red. M. Pazdan, s. 977-978.

${ }^{70}$ Ibidem.

${ }^{71}$ Ibidem, s. 976-977. Należy przyjąć, że o tym, czy doszło do „zamknięcia stanu faktycznego" prowadzącego do wywołania skutku rzeczowego, rozstrzyga prawo państwa, w którym została dopełniona ostatnia przesłanka wymagana przez to prawo do wywołania skutku rzeczowego. Tak: J. Górecki, w: System, Tom 20B, Red. M. Pazdan, s. 978. 
ich substancji. Dlatego też są one często przenoszone, przewożone i zmieniają miejsce swego położenia. Z punktu widzenia poszukiwania statutu rzeczowego z wykorzystaniem łącznika miejsca położenia rzeczy, co do zasady, nieistotne jest przemieszczanie rzeczy na obszarze jednego państwa. Może to mieć jednak znaczenie w państwie, w którym obowiązuje prawo niejednolite ${ }^{72}$. Najczęściej przyjmuje się, że miejscem położenia rzeczy ruchomej jest jej faktyczne (rzeczywiste) miejsce położenia (situs naturalis), nawet gdy jest ono przejściowe (przypadkowe) i ulega częstym zmianom. Jest też bez znaczenia, czy zmiana położenia rzeczy była zgodna $\mathrm{z}$ wolą właściciela rzeczy ${ }^{73}$.

Niekiedy może pojawić się problem z ustaleniem łącznika w przypadku rzeczy ruchomej, jeżeli miejsce położenia rzeczy nie jest znane nawet właścicielowi. Niektóre ustawy kolizyjne zawieraja odpowiednie rozwiązania, które mogą być pomocne przy poszukiwaniu miarodajnego łącznika ${ }^{74}$. W literaturze proponuje się przyjęcie rozwiązania, iż w razie nieznajomości miejsca położenia rzeczy ruchomej, dla dokonania związanych $\mathrm{z}$ nią czynności prawnych $\mathrm{z}$ zakresu prawa rzeczowego należy dochować wymagań ostatniego znanego miejsca położenia rzeczy. Jednak gdyby ex post okazało się, że w chwili dokonywania danej czynności prawnej rzecz znajdowała się w innym państwie niż państwo ostatniego znanego miejsca położenia rzeczy i nadal tam pozostaje, to o skuteczności dokonanej czynności prawnej powinno decydować prawo tego innego państwa ${ }^{75}$.

Omawiany łącznik budzi wątpliwości co do wskazania prawa właściwego dla oceny skuteczności nabycia (ustanowienia) prawa w sytuacji, gdy przesłanki warunkujące powstanie prawa są rozciagnięte w czasie i gdy nie zostały jeszcze dopełnione, podczas gdy nastąiło przemieszczenie przedmiotu praw rzeczowych do innego państwa, a tym samym doszło do zmiany statutu ${ }^{76}$. Przykładem może być ocena skuteczności usta-

72 Ibidem, s. 957.

${ }^{73}$ Ibidem, s. 958.

${ }^{74}$ Jako przykład podaje się art. 10:132 ust. 1 KC niderl., który stanowi on, że jeżeli właściciel utracił posiadanie rzeczy i nie wiadomo, gdzie ona się znajduje, wówczas skutki prawnorzeczowe czynności prawnych dokonywanych przez właściciela lub jego następcę prawnego oceniać należy według prawa państwa, w którym rzecz znajdowała się w chwili utraty posiadania. J. Górecki: Kolizyjne prawo rzeczowe, s. 15; Idem, w: System, Tom 20B, Red. M. Pazdan, s. 958.

75 J. Górecki: Kolizyjne..., s. 15; J. Górecki, w: System, Tom 20B. Red. M. Pazdan, s. 958.

${ }^{76}$ J. Gołaczyński, P. Rodziewicz: Prawo właściwe..., s. 1199. Jak wskazują przywołani autorzy, kwestia ta została rozwiązania w prawie kolizyjnym Estonii (par. 18 (3)) estońskiej ustawy o prywatnym międzynarodowym, który przewiduje, że jeżeli rzecz ruchoma została przeniesiona do Estonii i powstanie lub ustanie prawa własności nie 
nowienia zastawu, gdy po zawarciu umowy zastawniczej w państwie A, rzecz została przewieziona do państwa B i tam nastąpiło wydanie rzeczy zastawnikowi. Powstaje wówczas pytanie, który łącznik miarodajny będzie dla oceny, w oparciu o jaki statut należy dokonać weryfikacji przesłanek, czy doszło do ustanowienia ograniczonego prawa rzeczowego ${ }^{77}$. Na gruncie p.p.m. z $1965 \mathrm{r}^{78}$ w kontekście oceny przesłanek nabycia własności rzeczy ruchomej od nieuprawnionego wypowiedział się SN w uchwale składu 7 sędziów z 30 marca 1992 r., wskazując, że „Dla oceny skuteczności umowy sprzedaży samochodu, skradzionego za granica, a znajdującego się w chwili zawarcia umowy w Polsce, właściwe jest, stosownie do przepisu art. $24 \S 2$ ustawy z dnia 12 listopada 1965 r. Prawo prywatne międzynarodowe (Dz.U. Nr 46, poz. 290 ze zm.) prawo polskie"79. Zdaniem SN, decydujacy jest ostatni statut, pod rządem którego nastąpiło „zamknięcie” danego stanu faktycznego podlegającego ocenie ${ }^{80}$.

Najwięcej problemów sprawia ustalenie miejsca położenia prawa stanowiacego przedmiot prawa rzeczowego. Przedmiotem praw rzeczowych w poszczególnych systemach prawnych nie są bowiem wyłacznie rzeczy. Moga nimi być także inne dobra ekonomiczne ${ }^{81}$. Polskie prawo kolizyjne, poza rozwiązaniami przyjętymi w art. 44 p.p.m., określajacymi prawo właściwe dla prawa wynikajacego z zapisu papieru wartościowego na rachunku w systemie rozrachunku papierów wartościowych ${ }^{82}$ oraz w art. 13 ustawy z 2 kwietnia 2004 r. o niektórych zabezpieczeniach

zostało zakończone w państwie obcym, uważa się że wydarzenia, które miały w państwie obcym, miały miejsce w Estonii. Zob. tłum. N. Żytkiewicz: Estońskie prawo prywatne międzynarodowe $i$ międzynarodowe postępowanie cywilne, „Kwartalnik Prawa Prywatnego" 2010, Nr 1, s. 222.

77 J. Gołaczyński, P. Rodziewicz: Prawo właściwe..., s. 1199.

${ }^{78}$ Ustawa z dnia 12 listopada 1965 r. prawo prywatne międzynarodowe, Dz.U. Nr 46, poz. 290 ze zm., dalej: p.p.m. z 1965 r.

${ }^{79}$ Uchwała SN (7) z 30 marca 1992 r., III CZP 17/92, OSNCm1992, Nr 11, poz. 186.

80 Tamże.

81 J. Górecki: Kolizyjne..., s. 15 i n.; J. Górecki, w: System, Tom 20B, Red. M. Pazdan, s. 958 i n.; M. Pazdan: Prawo prywatne międzynarodowe, s. 261; M. Tomaszewski, w: Prawo prywatne międzynarodow. Red. J. Poczobut, s. 688.

${ }^{82}$ Zob. szerzej M. Glicz, w: System, Tom 20B. Red. M. Pazdan, s. 1019 i n.; Idem: Lex cartae sitae $w$ obrocie zdematerializowanymi papierami wartościowymi. W: Wspótczesne wyzwania prawa prywatnego międzynarodowego. Red. J. Poczobut. Warszawa 2013, s. 82 i n.; O. Tytoń: Kolizyjnoprawne problemy rachunków papierów wartościowych - uwagi na tle art. 44 ustawy - Prawo prywatne międzynarodowe. W: Znad granicy ponad granicami. Księga dedykowana Profesorowi Dieterowi Martinemu. Red. M. Margoński, M. Krzymuski, Warszawa 2014, s. 299 i n. 
finansowych ${ }^{83}$, a także w art. 14 ust. 3 rozporządzenia Rzym I ${ }^{84}$, który reguluje ustanowienie zastawu lub innego zabezpieczenia na wierzytelności ${ }^{85}$, nie zawiera regulacji odnośnie tej kwestii.

Zasadniczo więc prawa właściwego dla praw rzeczowych ustanawianych na prawach należy poszukiwać w oparciu o ogólną regułę z art. 41 p.p.m. (legis rei sitae). Jednakże, czy można mówić o miejscu położenia prawa? ${ }^{86} \mathrm{~W}$ doktrynie wypowiedziano trafny pogląd, że nie można mówić de facto o miejscu położenia ani lokalizacji w stosunku do tego, czego nie można dotknąć ani przemieścić ${ }^{87}$. Zgłaszane są różne propozycje odnośnie „umiejscowienia praw” będących przedmiotem praw rzeczowych. Proponuje się, aby w przypadku, gdy prawo ma swój tzw. „zmysłowy punkt odniesienia” w postaci rzeczy, przyjąć, że do oceny prawa rzeczowego na tym prawie należy stosować w pierwszej kolejności prawo miejsca położenia tej rzeczy ${ }^{88}$. Przykładowo dla subintabulatu prawem właściwym będzie miejsce położenia nieruchomości ${ }^{89}$. W przypadku zastawu na akcjach, prawem właściwym jest prawo państwa położenia dokument (lex carte sitae), podczas gdy stosunek prawny inkorporowany w akcjach

${ }^{83}$ Dz.U. z 2016 r. poz. 891 ze zm.

${ }^{84}$ Rozporządzenie Parlamentu Europejskiego i Rady (WE) nr 593/2008 z dnia 17 czerwca 2008 r. w sprawie prawa właściwego dla zobowiązań umownych (Rzym I) (Dz. Urz. UE L 177 z 04.07.2008 r., str. 6).

${ }^{85}$ Do zastawu na wierzytelności w państwach UE należy stosować w stosunkach między zastawca a zastawnikiem ustalone na podstawie rozporządzenia Rzym I prawo właściwe dla umowy między nimi zawartej (w tym także ustalone w drodze wyboru prawa). Natomiast prawu właściwemu dla wierzytelności stanowiącej przedmiot zastawu poddać należy m.in. stosunki między zastawnikiem a dłużnikiem oraz dopuszczalność obciążenia wierzytelności zastawem (art. 14 ust. 2 Rozporządzenia Rzym I). Tak: J. Górecki, w: Międzynarodowe prawo handlowe, System Prawa Handlowego t. 9. Red. W. Popiołek. Warszawa 2013, s. 539-540.

86 J. Gołaczyński, P. Rodziewicz: Prawo właściwe..., s. 1203.

${ }^{87}$ M.P. Zachariasiewicz: Zastaw na wierzytelności w prawie prywatnym międzynarodowym, „Kwartalnik Prawa Prywatnego” 2008, Nr 1, s. 115, który przywołuje przytoczony pogląd P. Rogerson oraz wypowiedź U. Drobing, iż „przedmioty niematerialne (w tym wierzytelności) nie podlegają zasadzie właściwości legis rei sitae, ponieważ prawa nie posiadają jednoznacznego miejsca położenia, w którym zabezpieczony wierzyciel albo inni wierzyciele (lub państwo) mogliby przejąć na nimi kontrolę".

88 J. Górecki: Kolizyjne prawo rzeczowe, s. 16; J. Górecki, w: System, Tom 20B, Red. M. Pazdan, s. 959; J. Gołaczyński, P. Rodziewicz: Prawo właściwe..., s. 1203; odmiennie F. Zoll, Międzynarodowe prawo prywatne w zarysie, Kraków 1947, s. 61 , który proponował, aby prawo właściwe dla wierzytelności rozstrzygało także o prawach rzeczowych na tej wierzytelności.

89 J. Górecki: Kolizyjne..., s. 16; J. Górecki, w: System, Tom 20B, Red. M. Pazdan, s. 959; J. Gołaczyński, P. Rodziewicz: Prawo właściwe..., s. 1203. 
podlega prawu państwa siedziby osoby prawnej ${ }^{90}$. Natomiast, gdy prawo będące przedmiotem prawa rzeczowego pozbawione jest materialnego punktu odniesienia, prawem właściwym dla praw rzeczowych na tym prawie jest prawo państwa, któremu prawo to podlega ${ }^{91}$. Sformułowanie to, choć pojawiajace się dość powszechnie w doktrynie, nie jest dostatecznie jasne ${ }^{92}$. Stąd na konkretnych przykładach próbuje się określić zakres znaczeniowy tego pojęcia. I tak wskazuje się, że prawa udziałowe w spółce będące przedmiotem prawa rzeczowego (np. zastawu), jako prawu właściwemu podlegaja prawu państwa siedziby spółki, ale już zastaw na wierzytelności podlega prawu właściwemu dla stosunku prawnego będącego źródłem tej wierzytelności ${ }^{93}$. Zastaw na rachunku bankowym podlega prawu właściwemu dla siedziby banku ${ }^{94}$.

Pojawiaja się także inne propozycje rozwiązania problemu miejsca położenia prawa - przedmiotu prawa rzeczowego, w odniesieniu do praw zastawniczych, mianowicie, aby przyjać: 1) prawo, któremu podlega zastawiana wierzytelności; 2) prawo wyznaczone łącznikiem siedziby (miejsca zamieszkania) jej dłużnika; 3) prawo siedziby (miejsca zamieszkania) jej wierzyciela; 4) prawo państwa, które wykazuje najściślejszy związek z ową wierzytelnościa ${ }^{95}$. Chodzi przy tym o wierzytelności, które nie maja materialnego punktu odniesienia ${ }^{96}$.

Jak widać na gruncie stosunków prawnorzeczowych stosowane są zasadniczo łączniki obiektywne. Autonomia woli stron przy poszukiwaniu i ustalaniu statutu rzeczowego na gruncie polskiego prawa kolizyjnego nie jest dopuszczana ${ }^{97}$, za wyjątkiem sytuacji przewidzianej w art. 14 ust. 3 rozporządzenia Rzym I oraz gdy strony przez zmianę miejsca po-

${ }^{90}$ J. Gołaczyński, P. Rodziewicz: Prawo właściwe..., s. 1203; E. Drozd: Zastaw $w$ prawie prywatnym międzynarodowym. W: Rozprawy $z$ polskiego $i$ europejskiego prawa prywatnego. Księga pamiatkowa ofiarowana Profesorowi Józefowi Skapskiemu, Kraków 1994, s. 36.

${ }^{91}$ J. Gołaczyński, P. Rodziewicz: Prawo właściwe..., s. 1203; E. Drozd: Zastaw $w$ prawie prywatnym międzynarodowym, s. 36; J. Górecki: Kolizyjne..., s. 16; J. Górecki, w: System, Tom 20B, Red. M. Pazdan, s. 959.

${ }^{2}$ J. Gołaczyński, P. Rodziewicz: Prawo właściwe..., s. 1203; E. Drozd: Zastaw $w$ prawie prywatnym międzynarodowym, s. 36; J. Górecki: Kolizyjne..., s. 16, J. Górecki, w: System, Tom 20B, Red. M. Pazdan, s. 959.

93 J. Gołaczyński, P. Rodziewicz: Prawo właściwe..., s. 1203; E. Drozd: Zastaw $w$ prawie prywatnym międzynarodowym, s. 36; J. Górecki: Kolizyjne..., s. 16; J. Górecki, w: System, Tom 20B, Red. M. Pazdan, s. 959. Co do możliwych rozwiazań zob. też M.P. Zachariasiewicz: Zastaw na wierzytelności..., s. 115 i n.

${ }^{94}$ M.P. Zachariasiewicz: Zastaw na wierzytelności..., s. 117.

${ }^{95}$ Ibidem, s. 117 i n.

${ }^{96}$ Ibidem.

${ }^{97}$ Wyrok SA w Krakowie z dnia 24 września 2014 r., I ACa 722/14, Legalis Nr 1171967; wyrok SN z dnia 11 marca 2011 r., II CSK 435/10, Legalis Nr 348441. 
łożenia rzeczy ruchomej mogą wpływać na właściwość prawa ${ }^{98}$. Także w obcych ustawach kolizyjnych wybór prawa jest stosowany wyjątkowo i nie jest wykorzystywany na szerszą skalę ${ }^{99}$. Jednak już od dawna pojawiają się postulaty poszerzenia zakresu autonomii woli w sferze kolizyjnego prawa rzeczowego ${ }^{100}$. Postulaty te coraz częściej zyskują aprobatę i do ustaw kolizyjnych wprowadza się rozwiązania wykorzystujące autonomię woli stron ${ }^{101}$ także w zakresie praw rzeczowych.

\section{Zakres statutu rzeczowego dla ograniczonych praw rzeczowych}

Katalog zdarzeń cywilnoprawnych, które według systemów merytorycznych moga powodować powstanie prawa rzeczowego, jest różnorodny. Niektóre regulowane sa przez prawo rzeczowe (np. zasiedzenie), inne natomiast przez inne działy prawa cywilnego (np. dziedziczenie - przez prawo spadkowe, nabycie w ramach stosunków majątkowych małżeńskich - prawo rodzinne itp.). W związku z powyższym zachodzi potrzeba określenia prawa właściwego dla zdarzenia powodujaceego powstanie prawa rzeczowego. Art. 41 ust. 2 p.p.m., określając właściwość prawa dla skutków zdarzenia, przesądza zarazem, że prawo to będzie w zasadzie decydować także o tym, jakie zdarzenia mogą te skutki wywołać. Inaczej

98 J. Górecki, w: System, Tom 20B, Red. M. Pazdan, s. 942.

${ }^{99}$ Zob. szerzej: J. Górecki, w: System, Tom 20B, Red. M. Pazdan, s. 942.

${ }^{100}$ Zob. np. E. Drozd: Nabycie i utrata praw rzeczowych, s. 72 i n.; J. Górecki, w: System, Tom 20B, Red. M. Pazdan, s. 941-942.

${ }^{101}$ Zob. np. art. 104 i 105 SzwajcU z 1987 r., art. 10:128 ust. 2 KC niderl., art. 1.49 KC lit., $§ 20$ ust. 2 EstU, art. 53 lit. a RumU z 1992 r. Daleko idące i nowatorskie są rozwiązania przyjęte w ChińskaU. W art. $37 \mathrm{zd}$. 1 dopuszcza się tam wybór prawa dla praw rzeczowych odnoszących się do rzeczy ruchomych. Wybór prawa jest też dopuszczalny dla zmiany praw rzeczowych na rzeczach w transporcie (art. $38 \mathrm{zd}$. 1). Podobne rozwiązania znaleźć można także w art. 1120 ust. 1 (nabycie i utrata praw rzeczowych na podstawie czynności prawnej) oraz w art. $1122 \mathrm{KC}$ biał. (rzeczy w transporcie). Również w UkrU dopuszcza się wybór prawa dla praw rzeczowych na rzeczach w transporcie (art. 41 ust. 1), dla powstania i ustania praw rzeczowych następujących na podstawie czynności prawnej, choć wybór taki nie może jednak naruszać praw osób trzecich (art. 39 ust. 2) oraz dla ochrony praw rzeczowych. W tym ostatnim przypadku jest on ograniczony do wyboru między legem rei sitae a legem fori (art. 42 ust. 1). Podaję za: J. Górecki, w: System, Tom 20B, Red. M. Pazdan, s. 941-942. 
mówiąc, to statut rzeczowy określa ilość i rodzaj przesłanek potrzebnych dla powstania, nabycia lub utraty prawa rzeczowego ${ }^{102}$.

Co jednak istotne, przepis art. 41 ust. 2 p.p.m. nie przesądza o właściwości prawa dla wszystkich poszczególnych przesłanek (elementów stanu faktycznego), które warunkują powstanie danego ograniczonego prawa rzeczowego. W tym kontekście pojawia się zagadnienie właściwości różnych statutów w odniesieniu do poszczególnych przesłanek ${ }^{103}$.

Coraz częściej w ustawach kolizyjnych wskazuje się na najważniejsze elementy statutu rzeczowego ${ }^{104}$. Polska ustawa kolizyjna z 2011 r. dość enigmatycznie określa ten zakres wskazując, że statutem objęte sa „nabycie i utrata własności, jak również nabycie i utrata oraz zmiana treści lub pierwszeństwa innych praw rzeczowych" (art. 41 ust. 2) ${ }^{105}$. Uszczegółowienie kwestii związanych ze statutem rzeczowym pozostawiono więc doktrynie i orzecznictwu. I tak przyjmuje się, że statut rzeczowy określa w pierwszym rzędzie, czy dane dobro jest rzeczą, wraz z dokonaniem kwalifikacji na rzecz ruchomą i nieruchomość, względnie, czy jest to inne dobro; czy dane dobro może być przedmiotem praw rzeczowych (ograniczonych praw rzeczowych), jeżeli tak to jakich. Rozstrzyga kwestię kwalifikacji części składowych i przynależności oraz czy moga stanowić one odrębny przedmiot praw rzeczowych (posiadania). Statut rzeczowy określa powstanie, pierwszeństwo, treść, przeniesienie, wreszcie wygaśnięcie praw rzeczowych. Z punktu widzenia interesującego nas zagadnienia, jakim jest powstanie ograniczonego prawa rzeczowego, statut rzeczowy określa, jakie zdarzenia prawne mogą być źródłem powstania ograniczonego prawa rzeczowego (czynność prawna, zasiedzenie, przepis prawa, orzeczenie sądu), co więcej, jakie jeszcze inne niezbędne przesłanki powinny być spełnione, aby doszło do powstania ograniczonego prawa

${ }^{102}$ E. Drozd: Nabycie i utrata praw rzeczowych, s. 11.

${ }^{103}$ Ibidem.

104 J. Górecki: Kolizyjne..., s. 20. Przykładowo, w art. 94 § 1 BelgU zakresem zastosowania prawa właściwego dla dóbr majątkowych (w tym rzeczy) obejmuje się w szczególności rozstrzygnięcie: czy rzecz jest nieruchomością, czy ruchomością, o istnieniu, naturze, treści i zakresie praw rzeczowych, podmiotach praw rzeczowych, dopuszczalności rozporządzania tymi prawami, sposobach ustanowienia, zmiany treści, przeniesienia i wygasania praw rzeczowych i wreszcie o skuteczności prawa rzeczowego względem osób trzecich. Z kolei w art. 10:127 ust. $4 \mathrm{KC}$ niderl. do zakresu statutu rzeczowego zalicza się ustalenie tego, czy rzecz jest nieruchomościa, czy ruchomością, co stanowi część składową rzeczy, czy dopuszczalne jest przeniesienie własności rzeczy lub ustanowienie prawa do tej rzeczy, jakie sa przesłanki przeniesienia lub ustanowienia prawa rzeczowego, jakie prawa mogą być powiązane z rzeczą oraz naturę i treść tych praw, w jaki sposób doprowadzić można do powstania, zmiany, przeniesienia i wygaśnięcia tych praw oraz jak określić wzajemny stosunek tych praw. Tamże. Zob. też Ł. Ża rnowiec: Wptyw statutu...

105 J. Górecki: Kolizyjne, s. 20. 
rzeczowego $^{106}$. Na tle art. 24 ust. 2 p.p.m. z 1965 r. SN wskazał, że to, czy określony fakt lub zespół faktów pociagnął za sobą nabycie lub utratę prawa rzeczowego, podlega ocenie według prawa państwa, w którym przedmiot prawa rzeczowego znajdował się w chwili zaistnienia tego faktu lub zespołu faktów ${ }^{107}$.

Polska ustawa kolizyjna choć kładzie nacisk na skutki zdarzenia kreujacego prawo rzeczowe (nabycie prawa rzeczowego), to jednak jest oczywiste że skutków zdarzenia nie można traktować w całkowitym oderwaniu od samego zdarzenia. Statut, określając właściwość prawa dla skutków, przesądza zarazem, że prawo to będzie w zasadzie decydować o tym także, jakie zdarzenia mogą te skutki wywołać ${ }^{108}$. Statut rzeczowy określa ilość i rodzaj przesłanek potrzebnych dla nabycia i utraty praw rzeczowych ${ }^{109}$. Co jednak istotne, statut rzeczowy nie przesądza o właściwości prawa dla poszczególnych przesłanek (elementów stanu faktycznego) powstania i utraty prawa rzeczowego ${ }^{110}$. Ma to istotne znaczenie z punktu widzenia oceny, jakie prawo ma rozstrzygać o tym, czy doszło do skutecznego ustanowienia ograniczonego prawa rzeczowego. W tym kontekście pojawia się zagadnienie właściwości różnych statutów w odniesieniu do poszczególnych przesłanek warunkujących powstanie prawa.

Jeżeli do ustanowienia ograniczonego prawa rzeczowego dochodzi w drodze czynności prawnej, może dojść do głosu wiele różnych modeli takich czynności: abstrakcyjna umowa rzeczowa, kauzalna umowa rzeczowa, abstrakcyjna umowa rzeczowa oraz przeniesienie posiadania, umowa zobowiązująco-rozporządzająca, umowa zobowiązująco-rozporządzająca oraz dodatkowa czynność, np. wydanie rzeczy, wpis do rejestru $^{111}$. Pojawia się kwestia określenia statutu dla danej umowy kreujacej ograniczone prawo rzeczowe.

Statutowi rzeczowemu podlegają przesłanki ważności umowy rzeczowej $^{112}$, z wyjątkiem kwestii dotyczacych zdolności oraz w pewnym stopniu formy (zob. art. 25 ust. 2 p.p.m.). Statut rzeczowy rozstrzyga o kauzalnym lub abstrakcyjnym charakterze umowy rzeczowej. Jednak już umowa zobowiązująca nie będzie objęta statutem rzeczowym ${ }^{113}$, powszechnie przyjmuje się w tym zakresie wyłączną właściwość statutu

\footnotetext{
${ }^{106}$ Zob. wyr. SN z dnia 11 marca 2011 r., II CSK 435/10, Legalis Nr 348441.

${ }^{107}$ Wyr. SN z dnia 22.03.2002 r., I CKN 1137/99, OSNC 2003, nr 4, poz. 51.

108 E. Drozd: Nabycie i utrata praw rzeczowych, s. 11.

${ }^{109}$ Ibidem.

110 Ibidem.

111 Ibidem.

${ }^{112}$ M.in. ocena materialnoprawnych przesłanek ważności (dopuszczalności) umów o podwójnym skutku. J. Górecki, w: System, Tom 20B, Red. M. Pazdan, s. 972.

${ }^{113}$ Wyr. SN z dnia 11 marca 2011 r., II CSK 435/10, Legalis Nr 348441.
} 
obligacyjnego ${ }^{114}$. Podobnie, mimo dość rozbieżnych poglądów w tym zakresie, dla umowy o podwójnym skutku, decydujace znaczenie przypisuje się statutowi obligacyjnemu ${ }^{115}$ i dopuszczalnej w tym zakresie autonomii woli stron. Także kwestia pełnomocnictwa dla zawarcia umów kreujacych prawo rzeczowe nie będzie objęta statutem rzeczowym (będzie objęta statutem pełnomocnictwa), ale już kwestia, czy dana umowa może zostać zawarta przez pełnomocnika będzie rozstrzygana przez statut rzeczowy ${ }^{116}$.

Statut rzeczowy określa liczbę i rodzaj przesłanek potrzebnych do powstania, nabycia i utraty praw rzeczowych. Chodzi tu zarówno o przesłanki pozytywne, jak i negatywne (tzn. wyłaczajace wystąpienie wskazanych zdarzeń prawnych). Dotyczy to np. obowiązku wydania nabywcy przedmiotu praw rzeczowych oraz sposobu jego realizacji, dopełnienia innych przejawów powszechnie przyjmowanej zasady jawności praw rzeczowych, zakazu ustanawiania lub przenoszenia praw rzeczowych z zastrzeżeniem warunku lub terminu. Statut rzeczowy określa wreszcie, $\mathrm{z}$ jaka chwilą następuje powstanie (przeniesienie) prawa rzeczowego będace efektem dokonanej czynności prawnej ${ }^{117}$. Statut rzeczowy określa także, jakie przymioty powinien spełniać podmiot uprawniony do ustanowienia danego prawa rzeczowego oraz na rzecz jakiego podmiotu ${ }^{118}$ może być ustanowione dane ograniczone prawo rzeczowe, wprowadzając niekiedy szczególne kryteria podmiotowe (zob. np. regulacje polskiej ustawy o timeshare ${ }^{119}$ ). Statut rzeczowy rozstrzyga, co należy rozumieć przez posiadanie, czy możliwe jest posiadanie w zakresie ograniczonego prawa rzeczowego i czy ten stan faktyczny (bądź prawo podmiotowe) ${ }^{120}$ może prowadzić do powstania ograniczonego prawa rzeczowego $\mathrm{w}$ drodze zasiedzenia ${ }^{121}$. Czy możliwe jest nabycie prawa rzeczowego od nieuprawnionego ${ }^{122}$. Ponadto, czy dane ustanowione prawo rzeczowe jest zbywalne czy niezbywalne, kto jest uprawniony do rozporządzania ogra-

114 E. Drozd: Nabycie i utrata praw rzeczowych, s. 12.

${ }^{115}$ Zob. szerzej J. Górecki: Kolizyjne..., s. 23-24; E. Drozd: Nabycie i utrata praw rzeczowych, s. 12.

${ }^{116}$ Ibidem, s. 21.

117 J. Górecki: Kolizyjne..., s. 20-21.

118 Ibidem, s. 21.

${ }^{119}$ Ustawa z dnia 16 września 2011 r. o timeshare, Dz.U. Nr 230, poz. 1370 ze zm.

${ }^{120}$ Posiadanie jest różnie kwalifikowane w poszczególnych systemach prawnych. Por. J. Górecki: Prawa rzeczowe i posiadanie..., s. 18; Idem: Kolizyjne..., s. 39; Idem, w: Prawo prywatne międzynarodowe. Komentarz. Red. M. Pazdan, kom. do art. 45, Legalis; K. Bagan-Kurluta: Prawo prywatne międzynarodowe, Warszawa 2011, s. 270.

${ }^{121}$ Por. E. Drozd: Nabycie i utrata praw rzeczowych, s. 11-12.

122 J. Górecki: Kolizyjne..., s. 22. 
niczonym prawem rzeczowym ${ }^{123}$, jakie muszą być kwalifikacje nabywcy prawa. Wreszcie statut rzeczowy jest właściwy dla określenia skutków wpisów w rejestrach publicznych, przesądzając, czy wpis do rejestru jest konieczna przesłanka powstania ograniczonego prawa rzeczowego oraz jakie sa inne następstwa ujawnienia ograniczonego prawa rzeczowego $\mathrm{w}$ rejestrze publicznym ${ }^{124}$. Statut rzeczowy, co oczywiste, określa treść danego ograniczonego prawa rzeczowego (prawa i obowiązki stron stosunku ograniczonego prawa rzeczowego), jego wykonywanie i ochronę ${ }^{125}$. Przesądza także o ewentualnej akcesoryjności ograniczonego prawa rzeczowego i ewentualnie o innych powiązaniach danego ograniczonego prawa rzeczowego z innym prawem ${ }^{126}$ (zob. np. art. 278 i 279 k.c.).

\section{Statut rzeczowy a inne statuty}

Problem rozgraniczenia statutu rzeczowego od innych statutów w procesie, który prowadzi do ustanowienia ograniczonego prawa rzeczowego, występuje dość często. Poza sygnalizowanymi już wcześniej kwestiami dotyczącymi formy czynności prawnej, pełnomocnictwa, zdolności prawnej i zdolności do czynności prawnych, pojawia się zagadnienie takich elementów stanu faktycznego, które towarzyszyć powinny określonemu zdarzeniu kreujaccemu dane ograniczone prawo rzeczowe. Chodzi tu o takie elementy stanu faktycznego jak: uprawnienie do rozporządzenia prawem, przymioty odnoszące się do przedmiotu ograniczonego prawa rzeczowego, stanowiącego przedmiot obciążenia, przymioty odnoszące się do podmiotów czynności prawnej, a nie wchodzące w skład zdolności i zdolności do czynności prawnych, wreszcie określony stan psychiczny (czyli dobra/zła wiara podmiotu), który nabywa (w sposób konstytutywny jak i translatywny) dane ograniczone prawo rzeczowe ${ }^{127}$. Ponadto, na co także należy zwrócić uwage przy konstytutywnym wykreowaniu ograniczonego prawa rzeczowego, powinien zaistnieć określony stan prawny ${ }^{128}$, który pozwoli $\mathrm{w}$ danym systemie prawnym na powstanie danego prawa jako ograniczonego prawa rzeczowego. Związane jest to z przyjęta

\footnotetext{
${ }^{123}$ Ibidem, s. 21.

${ }^{124}$ Ibidem, s. 22.

${ }^{125}$ Ibidem, s. 24.

${ }^{126}$ Ibidem, s. 25.

${ }^{127} \mathrm{Na}$ te elementy wskazywał E. Drozd w odniesieniu do przeniesienia własności. Zob. E. Drozd: Nabycie i utrata praw rzeczowych, s. 13.

${ }^{128}$ B. Ziemianin, Z. Kuniewicz: Prawo cywilne. Część ogólna, Poznań 2007, s. 70.
} 
w większości systemów prawnych zasadą numerus clausus praw rzeczowych.

Uprawnienie do obciążenia danego dobra ekonomicznego ograniczonym prawem rzeczowym powinno podlegać ocenie w oparciu o stosunek prawny, który stanowi źródło owego uprawnienia (np. stosunek własności, prawa użytkowania wieczystego, innego prawa rzeczowego). Uprawnienie do ustanowienia/powstania ograniczonego prawa rzeczowego może też wynikać z przepisu prawa (zob. np. art. 243 k.c.), czy aktu władzy publicznej (art. 112 u.g.n.) ${ }^{129}$. Niekiedy stosunek będący źródłem uprawnienia swoje umocowanie będzie lokował w obszarze prawa rodzinnego, spadkowego, czy obligacyjnego. W takich sytuacjach powinien znaleźć zastosowanie statut właściwy dla stosunku prawnego będącego źródłem owego uprawnienia ${ }^{130}$. Przymioty odnoszace się do przedmiotu ograniczonego prawa rzeczowego podlegaja statutowi rzeczowemu, o czym była już mowa, podobnie jak statut rzeczowy może wprowadzać określone wymagania co do podmiotów stosunku ograniczonego prawa rzeczowego, w tym wypadku ocena, czy mamy do czynienia np. z przedsiębiorca, nastapi w oparciu o inny statut - miejsce siedziby przedsiębiorstwa ${ }^{131}$. Stan psychiczny podmiotu nabywajaceego prawo rzeczowe, w szczególności dobra/zła wiara, podlega statutowi rzeczowemu ${ }^{132}$.

Kwestia konieczności dokonania rozgraniczenia poszczególnych statutów jest szczególnie widoczna, gdy do powstania ograniczonego prawa rzeczowego dochodzi na podstawie innego zdarzenia prawnego niż umowa $^{133}$. Trzeba bowiem pamiętać, że zdarzenia, które kreują ograniczone prawa rzeczowe, często swoje źródło maja w prawe rodzinnym i spadkowym. Statut rzeczowy nie obejmuje więc swym zakresem wszystkich zdarzeń prawnych, na których opiera się powstanie praw rzeczowych. Sa one często poddane odrębnym statutom. Najczęściej chodzi o statut obligacyjny, ale często chodzi o statut stosunków majątkowych między małżonkami lub o statut spadkowy ${ }^{134}$. Statut rzeczowy przesądza jedynie o tym, czy zdarzenia objęte zakresem innych statutów mogą stanowić podstawę dla m.in. powstania praw rzeczowych. Natomiast statut rzeczowy nie decyduje o dopuszczalności i przesłankach ważności czynno-

${ }^{129}$ Ustawa z dnia 21 sierpnia 1997 r. o gospodarce nieruchomościami, tekst jedn. Dz.U. z 2018 r. poz. 2204 ze zm. Zob. E. Drozd: Nabycie i utrata praw rzeczowych, s. 13.

${ }^{130}$ Ibidem.

${ }^{131}$ Ibidem, s. 14.

132 Ibidem.

${ }^{133}$ Także gdy źródłem ograniczonego prawa rzeczowego jest umowa, w zależności od charakteru prawnego tej umowy może dojść do głosu jako właściwy zarówno statut rzeczowy jak i obligacyjny. Zob. J. Górecki, w: System, Tom 20B, Red. M. Pazdan, s. $970-971$.

134 J. Górecki, w: System, Tom 20B, Red. M. Pazdan, s. 986-987. 
ści prawnych poddanych innym statutom oraz o innych okolicznościach, które pozwalaja przesądzić o tym, czy doszło do wystąpienia zdarzenia wywołującego także skutki rzeczowe ${ }^{135}$. W związku z tym poza zakresem statutu rzeczowego leżą np. domniemania o przynależności określonych przedmiotów majątkowych do majątku wspólnego albo odrębnego małżonków. Również to nie statut rzeczowy, a statut stosunków majątkowych małżeńskich przesądzi o dopuszczalności przesunięć majątkowych między występujacymi $\mathrm{w}$ tych stosunkach masami majątkowymi ${ }^{136}$. W oparciu o statut majątkowy następować może bowiem przeniesienie (przejście) praw rzeczowych i co do zasady odbywa się ono niezależnie od regulacji statutu rzeczowego ${ }^{362}$. W szczególności poza zakresem statutu rzeczowego leży także np. kwestia zgody współmałżonka na dokonanie rozporządzeń składnikami wspólnego majątku małżonków, w tym obciażenie danego składnika majątku wspólnego ograniczonym prawem rzeczowym (np. nieruchomości, przedsiębiorstwa, zob. np. art. 37 k.r.o. ${ }^{137}$ ). To w statucie stosunków majątkowych małżeńskich należy poszukiwać odpowiedzi na pytanie, czy w danym przypadku taka zgoda będzie wymagana oraz jakie konsekwencje będą wiązały się z brakiem wymaganej zgody $^{138}$.

Przykładem problemów, jakie mogą się pojawić na styku statutu rzeczowego i statutu spadkowego w kontekście skuteczności ustanowienia ograniczonego prawa rzeczowego, jest instytucja zapisu windykacyjnego, przewidziana m.in. w art. art. $981^{1} \S 2$ polskiego Kodeksu cywilnego. Problem z zapisem windykacyjnym wynika z faktu, że nie wszystkie systemy prawne przewiduja możliwość jego skutecznego ustanowienia ${ }^{139}$, a tym samym powstania prawa rzeczowego w drodze czynności mortis causa $\mathrm{z}$ chwilą otwarcia spadku. Zachodzi więc potrzeba określenia roli statutu rzeczowego przy ocenie skutków zapisu windykacyjnego ${ }^{140}$. W doktrynie słusznie podkreślono, że nie można kwestionować znaczenia statutu rzeczowego przy ocenie skutków zapisu windykacyjnego, jeżeli przedmiotem zapisu jest powołanie do istnienia ograniczonego prawa rzeczowego (por. art. $981^{1} \S 2$ pkt 4 k.c.). Do powstania - w wyniku zapisu windykacyjnego - ograniczonego prawa rzeczowego wymagane

${ }^{135}$ Ibidem.

${ }^{136}$ Ibidem.

${ }^{137}$ Ustawa z dnia 25 lutego 1964 r. Kodeks rodzinny i opiekuńczy, tekst jedn. Dz.U. z 2017 r., poz. 682 ze zm., dalej: k.r.o.

138 J. Górecki, w: System, Tom 20B, Red. M. Pazdan, s. 986-987; zob. też E. Drozd: Nabycie i utrata praw rzeczowych, s. 15.

${ }^{139}$ Zob. szerzej z omówieniem stanowiska doktryny polskiej i zagranicznej M. Pazdan: Aspekty kolizyjnoprawne zapisu windykacyjnego, „Problemy Prawa Prywatnego Międzynarodowego" 2015, tom 16, s. 14 i n. Zob. literaturę przywołaną w przyp. 144.

${ }^{140}$ M. Pazdan: Aspekty kolizyjnoprawne..., s. 16. 
jest spełnienie dwóch przesłanek: 1) statut spadkowy powinien taki przedmiot zapisu windykacyjnego przewidywać, 2) w drodze zapisu windykacyjnego może w danym państwie powstać i funkcjonować tylko takie ograniczone prawo rzeczowe, które znane jest prawu rzeczowemu obowiązującemu w tym państwie (czyli statutowi rzeczowemu) ${ }^{141}$.

W wyroku z 12 października 2017 r. ${ }^{142}$ TSUE wskazał, że art. 1 ust. 2 lit. k i l oraz art. 31 rozporządzenia $\mathrm{Nr}$ 650/2012 ${ }^{143}$ należy interpretować w ten sposób, że stoją one na przeszkodzie odmowie uznania przez organ państwa członkowskiego skutków rzeczowych zapisu windykacyjnego, znanego prawu właściwemu dla dziedziczenia wybranemu przez spadkobierce zgodnie z art. 22 ust. 1 tego rozporządzenia, gdy ta odmowa następuje w oparciu o uzasadnienie, w myśl którego zapis ten dotyczy prawa własności nieruchomości położonej w tym państwie członkowskim, którego ustawodawstwo nie zna instytucji zapisu wywierajacego bezpośredni skutek rzeczowy z chwilą otwarcia spadku. Przywołane orzeczenie rozwiewa dotychczasowe wątpliwości w obszarze dopuszczalnych skutków zapisu windykacyjnego ${ }^{144}$. Kwestia ta była, jeszcze przed wydaniem orze-

${ }^{141}$ Ibidem, s. 27.

${ }^{142}$ Wyr. TSUE z 12.10.2017 r., C.-218/16, Kubicka, „Monitor Prawniczy” 2017, Nr 22, s. 1184 .

${ }^{143}$ Rozporządzenie Parlamentu Europejskiego i Rady (UE) nr 650/2012 z dnia 4 lipca 2012 r. w sprawie jurysdykcji, prawa właściwego, uznawania i wykonywania orzeczeń, przyjmowania i wykonywania dokumentów urzędowych dotyczących dziedziczenia oraz w sprawie ustanowienia europejskiego poświadczenia spadkowego z dnia 4 lipca $2012 \mathrm{r}$. (Dz. Urz. UE.L Nr 201, str. 107).

${ }^{144}$ Por. J. Górecki: Zapis windykacyjny - uwagi de lege ferenda. W: Rozprawy $z$ prawa prywatnego, prawa o notariacie i prawa europejskiego ofiarowane Panu Rejentowi Romualdowi Sztykowi. Red. E. Drozd, A. Oleszko, M. Pazdan. Kluczbork 2007, s. 129 i n.; J. Pazdan: Ku jednolitemu międzynarodowemu prawu spadkowemu, „Rejent" 2005, Nr 3, s. 11; Eadem, w: System Prawa Prywatnego, Tom 20C, Warszawa 2015, s. 666; A. Wy s ocka-Bar: Wybór prawa w międzynarodowym prawie spadkowym, Warszawa 2013, s. 299-300; Eadem: Prawo wtaściwe dla dziedziczenia wedtug unijnego rozporzadzenia dotyczqcego spraw spadkowych, „Kwartalnik Prawa Prywatnego” 2012, Nr 4, s. 930-931; D. Martiny: Lex rei sitae as a connecting factor in EU Private International Law, „Praxis des Internationalen Privat- und Verfahrensrechts” 2012, t. 2, s. 128; odmiennie M. Margoński: Ausländische Vindikations nach EU-Erbrechtsverordnung, Zeitschrift für Gemeinschaftsprivatrecht 2013, t. 2, s. 105-110; J. Sch midt: Die Kollisionsrechtiche Behandlung dinglich wirkender Vermächtnisse - Ein Prüfstein für Grundfragen des internationalen und das materiellen Privatrechts, „Rabels Zeitschrift für ausländisches und internationales Privatrecht” 2013, t. 1, s. 1-30; M. Pazdan: Kolizyjnoprawna problematyka nabycia spadku, „Studia Cywilistyczne” 1974, t. 23, s. 169-171; Idem: Aspekty kolizyjnoprawne..., s. 14 i n.; zob. też K.A. Dadańska: Zapis windykacyjny — zagadnienia kolizyjnoprawne. W: Wspótczesne problemy Prawa rodzinnego i spadkowego, Red. M. Andrzejewski, K. Dadańska, Szczecin 2014, s. $165-186$. 
czenia przez TSUE, przedmiotem rozważań przede wszystkim doktryny niemieckiej, co wynikało z faktu, że prawo niemieckie nie przewiduje instytucji zapisu windykacyjnego ${ }^{145}$. Wskazywano, że w przypadku gdy spadkodawca ustanowił w testamencie zapis windykacyjny, dopuszczalny w niektórych prawach wewnętrznych państw członkowskich (a więc także od $2011 \mathrm{r}$. w prawie polskim) ${ }^{146}$, a prawem właściwym zgodnie z rozporządzeniem spadkowym będzie prawo niemieckie nieznające instytucji zapisu windykacyjnego, to wówczas zapis taki nie wywoła skutku rzeczowego w postaci przejścia prawa własność na spadkobiercę, lecz zostanie potraktowany jako zapis zwykły przewidziany w niemieckim prawie merytorycznym ${ }^{147}$. W polskiej doktrynie, jeszcze przez wydaniem przywołanego orzeczenia TSUE, podkreślano, że zapis windykacyjny wywoła bezpośrednie skutki prawnorzeczowe wówczas, gdy skutki takie łaczy z zapisem zarówno statut spadkowy, ale również statut rzeczowy z chwili otwarcia spadku. Przyjmowano, że zapis windykacyjny wywoła więc od razu skutki prawnorzeczowe, jeśli zarówno statut spadkowy, jak i statut rzeczowy posługują się konstrukcją zapisu o podwójnym skutku (legatum per vindicationem $)^{148}$. Natomiast dyskusyjna była kwestia, czy zapis testamentowy wywoła bezpośrednio skutki prawnorzeczowe, jeżeli skutki takie wiąże z zapisem statut rzeczowy, natomiast nie przewiduje tego statut spadkowy ${ }^{149}$. Pojawiła się koncepcja, aby w takiej sytuacji przypisać rozstrzygające znaczenie statutowi spadkowemu, który powinien mieć decydujące znaczenie przy rekonstrukcji rzeczywistej woli spadkodawcy i - co do zasady — powinien być spadkodawcy znany ${ }^{150}$. W kon-

${ }^{145}$ K.A. Dadańska: Zakres zastosowania rozporzadzenia spadkowego - uwagi na tle statutu spadkowego $i$ statutu stosunków majatkowych matżenskich $w$ świetle wniosku o wydanie orzeczenia $w$ trybie prejudycjalnym złożonego 3.11.2016 r. przez Kammergericht $w$ Berlinie (Niemcy). W: Kolizyjne i procesowe aspekty prawa rodzinnego. Red. J. Gołaczyński, W. Popiołek, Warszawa 2019, s. 21.

${ }^{146}$ Ustawa z dnia 18 marca 2011 r. o zmianie ustawy Kodeks cywilny oraz o zmianie niektórych innych ustaw (Dz.U. Nr 85, poz. 458).

${ }^{147}$ A. Wysocka-Bar: Wybór prawa..., s. 300; Eadem: Prawo wtaściwe..., s. 930931; D. Martiny: Lex..., s. 128; odmiennie M. Margoński: Ausländische..., s. 105110; J. Schmidt: Die Kollisionsrechtiche..., s. 1-30.

${ }^{148}$ M. Pazdan: Prawo prywatne międzynarodowe, 2017, s. 359; Idem: Kolizyjnoprawna problematyka..., s. 169-171; A. Wy socka-Bar: Wybór prawa..., s. 299; J. Górecki: Rozgraniczenie..., s. 195 i n.; K.A. Dadańska: Zapis windykacyjny..., s. 171 i n.

${ }_{149}$ M. Pazdan: Prawo prywatne międzynarodowe, 2017, s. 359 i n.; J. Gołaczyński: Prawo prywatne międzynarodowe, 2008, s. 311-312.

${ }^{150}$ K.A. Dadańska: Zapis windykacyjny..., s. 171 i n.; M. Pazdan: Aspekty kolizyjnoprawne..., s. 27, który wskazał: „Do powstania w drodze zapisu windykacyjnego ograniczonego prawa rzeczowego wystarczy, że prawo państwa miejsca położenia przedmiotu zapisu windykacyjnego zna ograniczone prawo rzeczowe, będące odpowiednikiem ograniczonego prawa rzeczowego przewidzianego w prawie stanowiącym statut spadko- 
tekście przywołanego wyroku TSUE brak podstaw do stwierdzenia, że zapis testamentowy może wywołać skutki rzeczowe, wyłącznie wówczas, gdy skutki takie przewiduje zarówno statut spadkowy, jak i statut rzeczowy $^{151}$.

Ponadto, pomimo że prawo właściwe w sprawach spadkowych ${ }^{152}$ dopuszcza ustanowienie danego ograniczonego prawa rzeczowego $\mathrm{w}$ testamencie, może pojawić się problem w sytuacji, gdy takie (ustanowione w testamencie) prawo nie jest znane na obszarze państwa, na którym skutki zapisu windykacyjnego mają się pojawićc153.

Obowiąujace unijne rozporządzenie spadkowe $\mathrm{Nr}$ 650/2012 przewiduje w takiej sytuacji możliwość dostosowania praw rzeczowych powstałych na podstawie statutu spadkowego do regulacji obowiąujących $\mathrm{w}$ miejscu położenia rzeczy. W przypadkach, gdy takie odpowiedniki można wskazać, należy dokonać wyboru prawa rzeczowego najbardziej zbliżonego do prawa ustanowionego $\mathrm{w}$ testamencie. W przypadku ujawnienia tego prawa w księdze wieczystej lub innym rejestrze organ dokonujący wpisu przeprowadzi weryfikację prawidłowości wyboru. Rodzi to dalsze komplikacje związane z koniecznościa porównywania treści przepisów wchodzących w skład statutu spadkowego i statutu rzeczowego. Po dostosowaniu prawo rzeczowe ustanowione w testamencie powinno uzyskać charakter i treść zgodną z prawem miejsca położenia rzeczy. Jeżeli brak jakiegokolwiek odpowiednika przyjąć wówczas można, że prawo rzeczowe nie powstanie. Dostosowanie nie zawsze jest bowiem możliwe, na co zwraca się uwage w treści art. 31 rozporządzenia ${ }^{154}$.

wy, które wskazał testator ustanawiający zapis windykacyjny. Dojdzie jednak wówczas do powstania ograniczonego prawa rzeczowego w kształcie przewidzianym przez statut rzeczowy".

${ }^{151}$ Zob. M. Pazdan: Kolizyjnoprawna problematyka..., s. 169-171; Idem: Aspekty kolizyjnoprawne..., s. 16 i n.; A. Wysocka-Bar: Wybór prawa..., s. 299; K.A. Dadańska: Zakres zastosowania rozporzqdzenia spadkowego, s. 22.

${ }_{152}$ Zob. art. 21 i 22 rozporządzenia spadkowego.

${ }^{153}$ J. Górecki: Rozgraniczenie statutu spadkowego $i$ statutu rzeczowego na tle rozporzadzenia spadkowego. W: Nowe europejskie prawo spadkowe. Red. J. Górecki, M. Pazdan, Warszawa 2015, s. 188 i n.

${ }^{154}$ J. Górecki, w: System, Tom 20B, Red. M. Pazdan, s. 988 i n. Ponadto spod zakresu statutu spadkowego wyłączono wpisy do rejestru (w tym do ksiąg wieczystych, zob. np. art. 29 u.k.w.h.). Zob. M. Pazdan: Aspekty kolizyjnoprawne..., s. 27. 


\section{Wnioski}

Ocena regulacji art. 41 ust. 2 p.p.m. skłania do następujących wniosków. Pojęcie „zdarzenia”, jakim posłużył się ustawodawca, należy interpretować jako stan faktyczny, z którym dane prawo merytoryczne wskazane przez łącznik normy kolizyjnej wiąże skutek w postaci powstania danego ograniczonego prawa rzeczowego. Co istotne, tego stanu faktycznego nie można ograniczyć wyłącznie do konwencjonalnego działania podmiotów prawa, kwalifikowanego jako zdarzenie prawne (czynność prawna, orzeczenie sądowe, akt władzy publicznej), ale raczej jako ogół przesłanek koniecznych dla powstania prawa, które poza samym zdarzeniem prawnym sensu stricto obejmuja takie elementy stanu faktycznego jak wydanie rzeczy, czy wpis do rejestru, a nawet stan psychiczny w postaci dobrej wiary podmiotu uprawnionego. Termin „nabycie” (ograniczonego prawa rzeczowego) należy odnieść zarówno do tych stanów faktycznych, gdy ograniczone prawo rzeczowe jest ustanawiane czynnością prawną (umową, czynnością jednostronna), ale także gdy powstaje na podstawie orzeczenia sądu, decyzji administracyjnej, a nawet ex lege. Miejsce położenia przedmiotu ograniczonego prawa rzeczowego to $\mathrm{z}$ reguły situs rei, jednak należy pamiętać, o czym była już mowa, że reguła ta zawodzi w przypadku ustanowienia ograniczonego prawa rzeczowego na prawie. W tym zakresie, dopóki nie zostaną wprowadzone odpowiednie rozwiązania $\mathrm{w}$ ustawie kolizyjnej, jak należy rozumieć miejsce położenia przedmiotu praw rzeczowych, gdy tym przedmiotem jest prawo, dopóty należy w procesie poszukiwania prawa właściwego udzielić odpowiedzi na pytania: - Czy dane prawo, będące przedmiotem obciążenia, posiada materialny punkt odniesienia? W razie odpowiedzi twierdzącej: - Czy ten materialny punkt odniesienia należy zastosować jako situs rei? Zaś w razie odpowiedzi przeczącej: - Czy dane ograniczone prawo rzeczowe obciąża np. prawa udziałowe w spółce (z o.o., akcyjnej), a jeżeli tak, czy należy zastosować jako prawo właściwe prawo siedziby osoby prawnej? I wreszcie, w razie przeczącej odpowiedzi na postawione wcześniej pytania - Czy prawo rzeczowe podlegające ocenie jest zwiazane z określoną wierzytelnościa, w ten sposób, że owa wierzytelność jest przedmiotem określonego prawa rzeczowego? Dokonana w ten sposób ocena pozwoli na wybór odpowiedniego łącznika wyrażonego dość nieudolnie w art. 41 ust. 2 p.p.m., jako situs rei, które oznaczać de facto może prawo miejsca położenia określonego przedmiotu materialnego związane fizykalnie z rzeczą obciążona prawem ograniczonym prawem rzeczowym będącym przedmiotem obciążenia, lex situs carte, prawo sie- 
dziby spółki, w której prawa udziałowe obciążone są np. użytkowaniem, czy prawo właściwe dla stosunku prawnego będącego źródłem danej wierzytelności obciążonej ograniczonym prawem rzeczowym na wierzytelności. Należy także pamiętać, że nie zawsze wyłącznie statut rzeczowy będzie miarodajny dla oceny wielu kwestii związanych z ustanowieniem ograniczonego prawa rzeczowego. Jest to szczególnie widoczne w obszarze stosunków majątkowych małżeńskich, gdzie inny niż rzeczowy statut może wprowadzić określone wymagania odnośnie możliwości skutecznego ustanowienia ograniczonego prawa rzeczowego, wyprzedzając $\mathrm{w}$ tym zakresie odpowiednie wymagania statutu rzeczowego. Przykładem jest art. 37 k.r.o., który wymaga zgody małżonka na dokonanie czynności prawnej, której przedmiotem jest m.in. obciążenie ograniczonym prawem rzeczowym nieruchomości. Nie ulega wątpliwości, że takim obciążeniem będzie ustanowienie ograniczonego prawa rzeczowego na nieruchomości. W takiej sytuacji, mimo spełnienia warunków ważności przewidzianej statutem rzeczowym, ocena czy rzeczywiście doszło do skutecznego ustanowienia prawa rzeczowego na nieruchomości objętej wspólnością majątkową małżeńską, będzie wymagała oceny przez pryzmat statutu stosunków majątkowych małżeńskich. W przypadku, gdy zdarzenie prawne kreujace dane ograniczone prawo rzeczowe umiejscowione zostanie w obszarze prawa spadkowego, należy dokonać oceny przesłanek ważności owego ustanowienia $\mathrm{z}$ punktu widzenia statutu spadkowego, a dopiero w dalszej kolejności statutu rzeczowego. Przy czym decydujace znaczenie dla oceny skutecznego ustanowienia prawa rzeczowego może mieć w tym przypadku inny niż rzeczowy — statut spadkowy. 